COMmentaRy on COVID-19 AND THE Food SyStem

\title{
Iteration, innovation, and collaboration: Supporting farmers markets' response to COVID-19
}

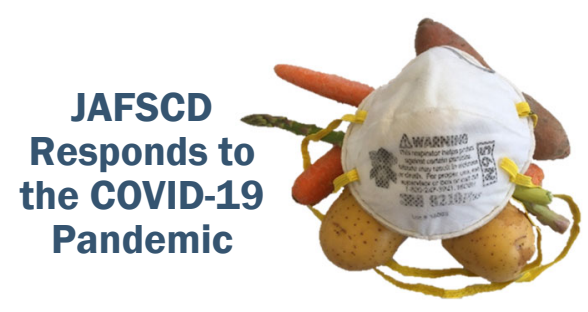

\author{
Diana Broadaway ${ }^{\mathrm{a}}$ * and Darlene Wolnik ${ }^{\mathrm{b}}$ \\ Farmers Market Coalition
}

Submitted September 25, 2020 / Published online November 4, 2020

Citation: Broadaway, D., \& Wolnik, D. (2020). Iteration, innovation, and

collaboration: Supporting farmers markets' response to COVID-19. Journal of

Agriculture, Food Systems, and Community Development, 10(1), 233-236.

https://doi.org/10.5304/jafscd.2020.101.009

Copyright (C) 2020 by the Authors. Published by the Lyson Center for Civic Agriculture and Food Systems. Open access under CC-BY license.

7 he value proposition of farmers markets has been altered by the COVID-19 pandemic. The festivallike features of markets put on hold, the in-person social interactions reduced, the physical flow of walk-up markets changed. Just as previous crises ${ }^{1}$ called upon markets to shift their operations to serve their community, the 2020 story highlights how once again, these low-capacity/high-functioning entities have been forced to reinvent themselves. This time, alternative models involving online pre-orders, drivethru, and curbside product pick-up scenarios have been rapidly put in place by individual vendors and market operators. Open-air and shed market vendor placements have been redesigned to allow for social distancing among both vendors and customers. Sanitation and public safety measures including gloves, hand sanitizer, and hand-washing facilities are now essential considerations.

The specific challenges faced by market organizations to implement those changes that have been reported to Farmers Market Coalition (FMC) and to its state and network-level partners ${ }^{2}$ include:

- Market-day operational restrictions due to public agency mandates that change regularly, ignoring the realities of outdoor retail venues and forcing significant redesign.

a * Corresponding author: Diana Broadaway, Training and Technical Assistance Network Coordinator, Farmers Market Coalition; P.O. Box 6497; Albany, CA 94706 USA; diana@,farmersmarketcoalition.org

b Darlene Wolnik, Training and Technical Assistance Director, Farmers Market Coalition; darlene@farmersmarketcoalition.org

1 https://www.youtube.com/watch?v=cxIbm-EyATs\&feature=youtu.be

2 https://farmersmarketcoalition.z2systems.com/np/clients/farmersmarketcoalition/publicaccess/membershipDirectory.do?md=2 
- A sharp decline in organizational revenue stemming from decreased vendor participation and funder disruptions.

- Increased expenses related to new safety measures, including additional staff needs and equipment purchases such as PPE and handwashing stations.

- Individual vendors' needs around evolving technology and marketing.

- The need to integrate online ordering, delivery, prepacked box programs, and other shopping and purchasing options.

- The expansion of the U.S. Department of Agriculture (USDA)'s SNAP online purchasing pilot ${ }^{3}$ in the spring and summer of 2020 (an important response to COVID, bringing online SNAP benefits to thousands of new households) is still only available when purchasing SNAP-eligible goods through larger retailers such as Amazon and Walmart. This pilot has yet to be extended to smaller retailers, including farmers markets and other direct-to-consumer outlets, once again leaving regional food economies largely out of the conversation around nutrition assistance.

These reports also indicate that the increased consumer interest in healthy options has buoyed local food systems, but not without added pressures: 93\% of the market operators who responded to FMC's May 2020 survey reported an increase in expenses associated with COVID-19 mitigation, and 74\% reported a loss in income frequently ascribed to the loss of sponsors or a reduction in the income via vendor fees. For example, at some markets vendor participation has dropped by one-third or more in 2020 over the same period in 2019 (Burger \& Benz, 2020). In a survey conducted by the California Alliance of Farmers Markets, nearly $20 \%$ of market operators expressed concern that they may not be able to sustain the economic impacts of COVID-19 over the long term (Feldman \& Creps, 2020).

\section{Resources and Networking}

In early March, the Farmers Market Coalition began to organize resources and advice collected from market operators developing COVID-mitigation strategies, including detail as to what was working and what was not. During this time, the state-level association leaders ${ }^{4}$ that FMC regularly convenes were doing the same with issues specific to their states, working with public health leaders ${ }^{5}$ to establish sensible guidelines for their markets. These documents and communications were organized into blog posts on FMC's website and included tips for staying informed at the municipal and state levels; guidance regarding market operations; examples of communications with vendors, customers, media, and the public; and policy changes and declarations. These posts also included policy documents, practical toolkits designed by markets and market organizations, news articles and op-eds, webinars, instructional photographs and videos, and planning materials. Market operators shared what they were learning in a series of FMC webinars, including Farmers Market Physical Redesign, Market-Tested Sales Platforms for Shopper Pre-Orders, and Thinking Inside the Box_Making Healthy Food Accessible with Curbside/Drive-Thru (Contactless) Models. Those tools and data are now housed in FMC's Resource Library to serve as permanent emergency response resources. Information continues to be added to this library as the pandemic and public health measures evolve.

The pandemic has also intensified the need for communities of practice and clarified FMC's role in providing a platform for innovation and collaboration. As part of this work, FMC is participating in a project managed by the USDA Agricultural Marketing Service and the University of Kentucky. The

\footnotetext{
${ }^{3}$ https://www.fns.usda.gov/snap/online-purchasing-pilot

4 https://www.mfma.org/COVID-19/

${ }^{5}$ https://extension.psu.edu/covid-19-vendor-tests-positive-or-exposed-to-someone-who-has
} 
Local Food Systems Response to COVID $^{6}$ project is drawing on the expertise of national agriculture and economic researchers working collaboratively with 17 local food marketing partners in assessing the overall impact of COVID-19 on local and regional food systems. In the summer of 2020, FMC shared an initial impact assessment of the sector with project collaborators detailing how the pandemic has affected market organizations, both socially and economically. That assessment will assist stakeholders in better understanding where to offer support and will also become the roadmap for FMC's resource development for market operators. Those resources include one or more innovation briefs highlighting alternative market models, led by the University of Kentucky, as well as a case study exploring the budgetary impacts of COVID-19 on flagship farmers markets. ${ }^{7}$ In addition, in September 2020, FMC conducted another national survey to solicit updated COVID impact data from market organizations, including the challenges posed and adaptations implemented during the summer 2020 market season. FMC will share the results of this survey with researchers from the Local Food Systems Response to COVID project and collaborate on analysis of the data. These initiatives are proving timely in the effort to collect valuable information and apply useful solutions to operational barriers for farmers markets, both in the near and long term. Cultivating relationships with other local and regional food systems leaders will be essential in navigating future crises, particularly those situations where supply chains are disrupted and vulnerable populations face further threats to food security.

\section{Advocacy}

In coordination with partners such as the National Sustainable Agriculture Coalition, National Young Farmers Coalition, Carolina Farm Stewardship Association, National Farmers Union, and the National Association of State Departments of Agriculture, FMC undertook significant advocacy efforts beginning early in the pandemic. The mid-March press release Family Farms and Farmers Markets Are Essential ${ }^{8}$ outlined the need to:

- explicitly include these businesses in any federal stimulus relief package to ensure that farmers markets are able to continue to operate while implementing best practices to minimize the spread of COVID-19;

- proposed adding flexibility to federal programs (including the Farmers Market and Local Food Promotion Program [FMLFPP], Value Added Producer Grants, and the Gus Schumacher Nutrition Incentive Program) affecting these outlets; and

- emphasized the importance of state and local government support in keeping farmers markets operational.

In an op-ed for Civil Eats titled We Must Save Farmers' Markets, ${ }^{9}$ which FMC co-authored with Heart of the City Farmers' Market, ${ }^{10}$ and a call to action ${ }^{11}$ delivered by FMC to urge senators to include support for farmers market operators in their consideration of the HEROES Act relief legislation, many issues were presented and potential solutions offered in an effort to gain the same support for the community

\footnotetext{
${ }^{6}$ https://lfscovid.localfoodeconomics.com/

7 The development of market types was first begun by the nonprofit Market Umbrella in its 2010 trans $\bullet$ act research, and has been continued by FMC in analyses such as the 2019 report for the city of Pittsburgh, Strengthening Pittsburgh's Farmers Markets (https:// farmersmarketcoalition.org/resource/understanding-and-improving-pittsburghs-farmers-markets/).

${ }^{8}$ https:// farmersmarketcoalition.org/wp-content/uploads/2020/03/Stimulus-Bill-COVID19-RELEASE-2020-FINAL.pdf

${ }^{9}$ https://civileats.com/2020/05/29/op-ed-we-must-save-farmers-markets/

10 https://heartofthecity-farmersmar.squarespace.com/

${ }^{11}$ https:/ / farmersmarketcoalition.org/ask-the-senate-to-provide-relief-to-farmers-market-operators /
} 
food system as the global industrial system. For example, the CARES Act, signed into law on March 27, 2020, provided Paycheck Protection Program (PPP) benefits to 501(c)(3) organizations and designated US $\$ 300$ million in additional funding for the Supplemental Nutrition Assistance Program (SNAP). However, these funds did not specifically target farmers markets or those entities managing incentive programs. ${ }^{12}$ As for farmers, the Coronavirus Food Assistance Program (CFAP) provides much-needed assistance to agricultural commodity producers facing supply chain interruptions and other significant costs associated with COVID, but does much less to help small farmers, including young and BIPOC farmers who may already face additional barriers in accessing capital, land, and markets (Figueroa \& Penniman, 2020).

\section{Conclusion}

Farmers Market Coalition regularly celebrates the role of local food systems - and farmers market organizations specifically_-in creating positive change. Yet, more stakeholders are needed to assist FMC and its state partners to ensure that markets remain welcoming and inclusive spaces for all who wish to participate, while also ensuring they receive sustained funding and policy support. The impact of COVID19 created rapid change, adaptation, and innovation in the farmers market sector and demonstrated its capacity for flexibility and resilience. FMC continues to amplify those successes while encouraging operators to seek site-specific data collection partnerships and foster collaborative learning both in and around their markets. For an increasing number of Americans, COVID-19 has highlighted the vulnerability of our food system and the value of having access to locally sourced, nutritious food. How and to what end markets and their partners apply what has been learned will assist entities like the Farmers Market Coalition in discerning how best to deploy their expertise and partnerships to develop positive sectorwide growth from this unprecedented challenge.

\section{References}

Burger, M., \& Benz, S. (2020, August 5). How has COVID-19 affected SFC farmers' markets? Sustainable Food Center. Retrieved from https:// sustainablefoodcenter.org/latest/blog/how-has-covid-19-affected-sfc-farmers-markets

Feldman, B., \& Creps, K. (2020, May 29). We must save farmers' markets [Op-ed]. Retrieved from https://civileats.com/2020/05/29/op-ed-we-must-save-farmers-markets/

Figueroa, M., \& Penniman, L. (2020, March). Land access for beginning and disadvantaged farmers. Data for Progress. Retrieved from https://filesforprogress.org/memos/land access for beginning disadvantaged farmers.pdf

\footnotetext{
12 The bills did not offer aid to other 501(c) and nonprofit incorporation types, under which many markets and other food assistance programs fall.
} 